\title{
Pendekatan relasi antar etnis untuk meningkatkan rasa solidaritas kebangsaan siswa SMA dalam pembelajaran sejarah
}

\author{
Wahyu Pambudi ${ }^{1}$ *, Sariyatun Sariyatun ${ }^{2}$, Akhmad Arif Musadad ${ }^{2}$ \\ ${ }^{1}$ Institut Keguruan dan Ilmu Pendidikan (IKIP) Persatuan Guru Republik Indoneisa (PGRI) Wates \\ Jalan KRT Kertodiningrat, Kulon Progo, Yogyakarta 55652, Indonesia \\ ${ }^{2}$ Magister Pendidikan Sejarah, Universitas Sebelas Maret. \\ Jalan Ir. Sutami No. 36 A, Jebres, Surakarta, Jawa Timur 57126, Indonesia. \\ Pambudiwahyu21@gmail.com \\ * Corresponding Author
}

\section{ARTICLE INFO}

\section{Article History}

Received:

24 January 2017

Revised:

23 May 2019;

Accepted:

28 November 2019

\section{Keywords}

Pembelajaran sejarah; Relasi antar etnis;

Solidaritas kebangsaan siswa;

History learning;

Inter-ethnics

correlation;

Student's national

solidarity

\begin{abstract}
ABSTRAK
Penelitian ini bertujuan untuk mengembangkan model pembelajaran sejarah Indonesia di SMA yang didesain dengan pendekatan relasi antar etnis dan mengevaluasi pengaruhnya terhadap peningkatkan rasa solidaritas kebangsaan siswa. Penelitian dilakukan menggunakan metode penelitian dan pengembangan (research and development, - R \& D) sesuai prosedur Borg \& Gall (2003). Subyek penelitian ini adalah siswa SMAN 1 Kota Kediri. Pengumpulan data menggunakan teknik dokumentasi, observasi dan angket. Analisis data statistik parametrik menggunakan bantuan program SPSS for windows versi 22.0. Hasil pengembangan menunjukkan bahwa model pembelajaran sejarah Indonesia berbasis relasi antar etnis (RAE) layak untuk diimplementasikan. Uji efektifitas model dengan teknik uji-t antar kelompok menunjukkan hasil t. 2,398, dengan taraf sig. 0,019 yang berarti model pembelajaran RAE efektif untuk meningkatkan rasa solidaritas kebangsaan siswa.

This research aims to develop a learning model of Indonesian history at senior high school which is designed by correlation approach among the ethnics and to evaluates the effect toward the improvement of students' national solidarity. The research was conducted by using research and development methods (R\&D) according to Borg \& Gall procedure (2003). The research subject was students of SMAN 1 Kediri City. The data collection used techniques of documentation, observation, and questionnaire. Data analysis of parametric statistics used program SPSS for Windows version 22.0. The result of development showed that the learning model of Indonesian history with inter ethnics correlation (IEC) based is feasible to be implemented. The effectiveness test of the model was by independent samples t-test technique showed the result $t$. 2,398 with sig. value 0,019, which means learning model CIE, is effective to improve students' national solidarity.
\end{abstract}

This is an open access article under the CC-BY-SA license.
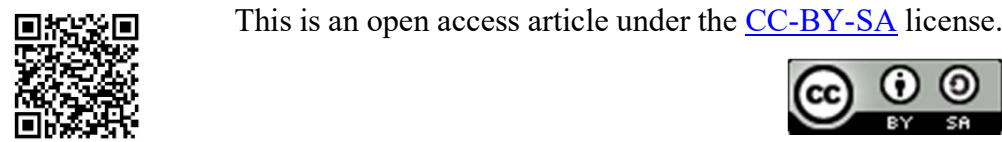


\section{PENDAHULUAN}

Bangsa Indonesia adalah bangsa yang pluralistik dan tentu dapat dikategorikan sebagai masyarakat majemuk. Beragam etnik mendiami bumi Indonesia, yang dalam satu daerah setiap individu yang berbeda etnik berinteraksi satu dengan yang lainnya. Kemajemukan kehidupan masyarakat inilah yang senantiasa mewarnai kehidupan masyarakat Indonesia (Romli, 2015, p. 5; Isnaini, 2016, p. 2). Bangsa Indonesia yang dikenal sebagai negara plural dari segi etnik dengan beragam ciri dan karakter sebagaimana yang diungkapkan Berghe, membutuhkan pengertian dan kearifan yang tinggi pada setiap masyarakatnya untuk secara lebih bijak bergaul dan berinteraksi dengan sesama warga masyarakat yang berbeda budaya dan etnik. Tanpa kearifan dan kerelaan untuk menerima perbedaan, maka akan timbul disharmoninya hubungan di antara mereka. Keragaman etnik itu juga yang membuat pola dan corak hubungan di antara masyarakat Indonesia terlihat begitu beragam. Berbagai kasus konflik yang disebabkan oleh multi budaya semakin meningkat dalam 20 tahun terahir, baik dari segi kualitas maupun dari segi kuantitasnya. Berbagai kasus konflik seperti: di Aceh, Timika (Papua), Ambon (Maluku), Pontianak (Kalimantan Barat), Sampit-Mataram (NTB) dan Poso (Sulawesi Tengah) adalah merupakan berbagai contoh kasus konflik SARA yang disebabkan oleh pertikaian antar etnis komunitas agama, atau antar golongan yang terjadi di berbagai kawasan di Indonesia (Ardi, 2017; \& Sutardi, 2007). Jika isu SARA ini sampai meletus menjadi konflik horizontal sangat sulit untuk menyelesaikannya. Bangsa Indonesia punya pengalaman atas konflik SARA sehingga perlu kesadaran para elit bahwa bermain-main dengan isu SARA risikonya sangat besar. Oleh karena itu, perlu menjadikan Pancasila sebagai solusi atas memudarnya solidaritas kebangsaan di Indonesia (Siswanto, 2019, p. 111).

Tujuan pendidikan sejarah di SMA sudah berkembang mengarah kepada pemahaman secara mendalam berbagai peristiwa sejarah yang dianggap penting untuk membangun kemampuan berpikir kritis, kemampuan belajar, rasa ingin tahu, kepedulian sosial dan semangat kebangsaan. Atas dasar pemikiran tersebut maka tujuan pendidikan sejarah di SMA adalah: 1.) Mengembangkan kemampuan berpikir kronologis, kritis dan kreatif; 2.) Membangun kepedulian sosial; 3.) Mengembangkan semangat kebangsaan; 4.) Membangun kejujuran, kerja keras, dan tanggungjawab; 5.) Mengembangkan rasa ingin tahu; 6.) Mengembangkan nilai dan sikap kepahlawanan serta kepemimpinan; 7.) mengembangkan kemampuan berkomunikasi; dan 8.) mengembangkan kemampuan mencari, mengolah, mengemas, dan mengkomunikasikan informasi (Hasan, 2012, p. 91). Solidaritas kebangsaan sesungguhnya nampak oleh unsur-usur rasa saling memiliki, empati, kerjasama, dan toleran. Maka rasa kebangsaan akan dibangun melalui pendidikan yang memberikan kesempatan kepada tiap individu yang notabene anggota dari suatu etnis, untuk bekerjasama, saling memiliki, toleran dan saling berempati dengan individu lain yang merupakan anggota dari etnis yang berlainan. Perlu suatu proses pembelajaran yang dengan sengaja menginternalisasikan relasi antar etnis untuk mengintervensi rasa solidaritas kebangsaan siswa. Inilah peran vital pendidikan sejarah dalam melestarikan konsep kebangsaan Indonesia. Maka pembelajaran sejarah difungsikan sebagai pembangun memori nasional, atau dalam bahasa menurut Budiawan (2013), melalui sejarah memori nasional constructed and imbricated (diciptakan dan dicangkokkan).

Pembelajaran sejarah dalam konteks kehidupan berbangsa dan bernegara sebenarnya memiliki peran yang sangat strategis. Hal ini karena pendidikan sejarah adalah mata pelajaran yang cukup tua dalam kurikulum pendidikan di Indonesia (Hasan, 2012, p. 60). Pembelajaran sejarah sebagai subsistem dari sistem kegiatan pendidikan, merupakan sarana yang efektif untuk meningkatkan integritas dan kepribadian bangsa melalui proses belajar mengajar. Integrasi bangsa sesungguhnya dapat diusahakan melalui eksperimen terhadap unsur-unsur pembentuknya. Dalam hal ini etnis dapat dipandang sebagai salah satu unsur pemersatu bangsa. Namun model asimilasi kebangsaan yang dipraktekkan orde lama dan orde baru bertolak belakang dengan premis tersebut diatas. Yaitu bahwa bangsa Indonesia bersifat unitarisme dan berusaha sebisa mungkin mereduksi identitas etnis dengan maksud meredam konflik antar etnis. Pasca reformasi, pandangan memendam identitas etnis untuk meredam konflik antar etnis tidak lagi relevan. Memendam identitas etnis hanya membuat bangsa Indonesia justru kehilangan karakteristiknya sebagai bangsa yang multi etnis.

Relasi antar etnis akan senantiasa membangun konsep kebangsaan Indonesia, namun pada hakikatnya ia tidak dapat bergeser dari kenyataan bahwa Indonesia adalah bangsa yang multietnis. 
\begin{tabular}{ll|l} 
Pendekatan relasi antar etnis untuk menungkatkan rasa ... & 147
\end{tabular}

Wahyu Pambudi, Sariyatun Sariyatun, Akhmad Arif Musadad

Konflik etnik tidak dapat direduksi hanya dengan jalan tidak menghiraukannya, menekannya, atau berpura-pura bahwa (potensi) konflik itu tidak ada (Susanto, 2003, p.108). Syarat integrasi bangsa adalah interaksi antar etnik yang bermakna dan rasa memiliki (sense of belonging) (Supardan, 2004, pp. 62-64). Berdasarkan, relasi antar etnis memungkinkan direkayasa sebagai pendekatan dalam pembelajaran sejarah dengan maksud memperkuat integrasi kebangsaan. Pengembangan model pembelajaran dalam penelitian ini didasarkan pada dua premis yaitu: pertama, bahwa pembelajaran sejarah kritis akan memberikan fondasi yang kuat atas memori kolektif yang ilmiah dan rasional, yang menjadi ikatan rasa kebangsaan. Kedua, komunikasi antar etnis dapat memperkokoh integrasi kebangsaan. Maka perlu dikembangkan suatu model pembelajaran yang dapat mengakomodir semua landasan-landasan teoritis atas premis tersebut.

Pembelajaran sejarah kritis adalah pembelajaran sejarah dengan teori konstruktivistik dan pendekatan saintifik. Teori kontruktivistik meletakkan landasan bahwa proses pendidikan terbaik adalah dengan memberikan keleluasaan kepada siswa untuk membangun pengetahuannya sendiri. Sedangkan pendekatan saintifik menekankan pada bagaimana siswa menggali informasi menggunakan langkah-langkah ilmiah. Di sisi lain, perkembangan ilmu sejarah saat ini telah memunculkan aliran yang disebut sebagai sejarah baru (the new history). Dimana peristiwa sejarah dianalisis dengan pendekatan ilmu sosial, dikaji secara struktural dan dengan paradigma interdisipliner. Perpaduan antara pembelajaran scientific dan the new history akan menjadi landasan atas pengembangan metode pembelajaran yang dikembangkan. Komunikasi antar etnis dalam pendidikan yang dapat memperkokoh integrasi kebangsaan pada hakikatnya adalah pendidikan demokrasi kebangsaan. Dalam kondisi masyarakat Indonesia yang heterogen, keterbukaan informasi, dan demokrasi, suatu unit sejarah harus dikelola secara cerdas. Bangsa Indonesia tersusun atas berbagai etnis, sehingga sesungguhnya sejarah bangsa Indonesia adalah jalinan interaksi antar etnis yang terakumulasi. Maka pendidikan demokrasi akan menempatkan etnis-etnis tersebut secara setara, dimunculkan untuk mengetahui perspektif yang berbeda, dan menggunakannya untuk membangun pemahaman yang komprehensif. Asumsi ini menyatakan bahwa pendidikan kebangsaan bukanlah menghapus atau mendistorsi etnisitas dan menggantikannya dengan kebangsaan tunggal yang homogen. Etnisitas tetap dipupuk agar terus berkembang dan pendidikan demokrasi penting untuk menjaga relasi antar etnis tersebut terjalin secara positif. Pendekatan relasi antar etnis itu pula yang akan mempengaruhi model pembelajaran yang dikembangkan.

Untuk itu peneliti memilih untuk memodifikasi dua metode belajar, guna mendapatkan karakteristik metode belajar yang mendekati karakteristik pembelajaran sejarah saintifik tersebut. Dua metode itu adalah Student Teams-Achievement Divisions (STAD) dan Group Investigation (GI), keduanya adalah model pembelajaran kooperatif. GI dipilih karena karakteristik langkah-langkah pembelajarannya ideal untuk prosedur penyelidikan peristiwa sejarah sedangkan STAD dipilih karena karakteristik pembentukan tim ideal untuk diterapkan dalam pembelajaran sejarah dengan multiperspektif berdasarkan multi etnis. Tujuan penelitian ini antara lain (1) mendeskripsikan hasil pengembangan model pembelajaran sejarah Indonesia berbasis relasi antar etnis di SMAN 1 Kota Kediri; (2) Mendeskripsikan efektivitas model pembelajaran sejarah Indonesia berbasis relasi antar etnis dalam meningkatkan rasa solidaritas kebangsaan pada siswa SMAN 1 Kota Kediri. Hasil penelitian ini dapat menjadi salah satu model yang bermanfaat bagi pengembangan mata pelajaran sejarah Indonesia selanjutnya, khususnya pengembangan pembelajaran sejarah sebagai pendidikan nilai, pendidikan demokrasi dan pendidikan karakter bangsa. Untuk memperjelas cakupan penelitian perlu ditegaskan beberapa definisi operasional dari beberapa istilah kunci yang digunakan, antara lain. Pembelajaran Sejarah adalah proses interaksi peserta didik dengan pendidik dan sumber belajar pada suatu lingkungan belajar untuk mengkaji suatu unit sejarah. Model pembelajaran adalah kerangka konseptual sebagai pedoman dalam melakukan kegiatan pembelajaran. Metode pembelajaran adalah tahapan atau langkah-langkah pembelajaran. Relasi antar etnis adalah hubungan yang bersifat timbal balik antara dua individu atau beberapa individu yang merasa bahwa mereka berada dalam kelompok yang berbeda secara etnis. Solidaritas kebangsaan adalah perasaan bersatu dan setia kawan sebagai sebuah bangsa. Adapun indikator solidaritas kebangsaan tersebut antara lain: rasa saling memiliki, empati, kerjasama dan toleran. 


\section{METODE}

Penelitian ini menggunakan pendekatan penelitian dan pengembangan (research and development), pendidikan yang dikembangkan oleh Gall, Gall, dan Borg (2003). Langkah-langkah research and development $(R \& D)$ yang diadopsi dikelompokkan menjadi tiga tahap, yaitu pertama, tahap studi pendahuluan atau penelitian pendahuluan dan pengumpulan informasi. Kedua, tahap pengembangan model, meliputi enam kegiatan: perencanaan, pengembangan desain awal produk, validasi ahli dan praktisi, revisi penyempurnaan produk, uji coba lapangan, dan revisi produk operasional (hipotetik). Ketiga, tahap evaluasi model, meliputi tiga kegiatan: uji efektifitas produk, produk akhir, dan diseminasi hasil pengembangan. Pengumpulan data menggunakan teknik dokumentasi, observasi dan angket. Pada tahap studi pendahuluan, teknik analisis data yang digunakan adalah deskriptif. Pada tahap pengembangan model menggunakan pendekatan penelitian tindakan (action research), oleh karena itu teknik analisis data yang digunakan adalah mixed methods (kuantitatif \& kualitatif). Tahap evaluasi model menggunakan metode eksperimen, teknik analisis data yang digunakan adalah uji-t antar kelompok (independent samples $t$-test). Analisis data statistik parametrik menggunakan bantuan program SPSS for windows versi 22.0. Penggalian data dilakukan pada semester gasal tahun ajaran 2015/2016 dengan subyek guru dan siswa kelas XI SMAN 1 Kota Kediri.

\section{HASIL DAN PEMBAHASAN}

Studi Pendahuluan terdiri dari studi pustaka, survey lapangan dan studi dokumentasi yang bertujuan mengetahui kondisi pembelajaran sejarah Indonesia yang selama ini dilakukan dan merumuskan analisis kebutuhan model yang dikembangkan. Hasil studi pendahuluan menunjukkan bahwa kualitas pembelajaran sejarah Indonesia perlu ditingkatkan, hal itu nampak dari (1) guru belum memandang penting sebuah perencanaan pembelajaran, (2) inovasi terhadap pendekatan, strategi, dan metode pembelajaran belum nampak serius dilakukan oleh guru, (3) guru hanya menitikberatkan evaluasi pada penilaian hasil belajar. Selain kondisi pembelajaran sejarah Indonesia yang perlu ditingkatkan, kondisi rasa solidaritas kebangsaan di kalangan siswa SMAN 1 Kota Kediri juga perlu ditingkatkan. Idealnya mayoritas siswa memiliki rasa solidaritas kebangsaan yang tinggi, sedangkan hasil survei menunjukkan hanya $23 \%$ siswa berada pada kategori tinggi dan sangat tinggi. Hasil survei ini menguatkan anggapan bahwa hasil pembelajaran sejarah Indonesia selama ini belum cukup maksimal berdampak pada solidaritas kebangsaan siswa. Adapun analisis kebutuhan pengembangan model adalah sebagai berikut: (1) penggunaan model pembelajaran kooperatif, (2) internalisasi materi relasi antar etnis dalam konten pembelajaran sejarah Indonesia, dan (3) penerapan authentic assesment (penilaian otentik). Berdasarkan studi pendahuluan kemudian perencanaan pengembangan model pembelajaran berbasis relasi antar etnis untuk meningkatkan rasa solidaritas kebangsaan siswa, secara sistematik dapat dilihat pada Gambar 1.

Meskipun pengembangan model meliputi enam unsur model yaitu: sintaks, sistem sosial, prinsip reaksi, sistem pendukung, dampak instruksional, dan dampak pengiring, namun rekayasa terutama nampak pada sintak pembelajaran. Ada dua metode pembelajaran yang akan digunakan sebagai dasar pengembangan yaitu STAD dan GI. STAD merupakan metode pembelajaran kooperatif dengan lima komponen utama, yaitu presentasi kelas, tim, kuis, skor kemajuan individual, dan rekognisi tim (Slavin, 2013, p.143). Sementara itu GI merupakan perencanaan pengaturan kelas yang umum dimana para siswa bekerja dalam kelompok kecil menggunakan pertanyaan kooperatif, diskusi kelompok serta perencanaan dan proyek kooperatif (Slavin, 2013, p.24). Dari hasil analisis kedua metode tersebut diatas, maka dikembangkan model pembelajaran berbasis relasi antar etnis. Bentuk awal model pembelajaran sejarah Indonesia berbasis relasi antar etnis (RAE) disusun dalam tiga komponen utama yaitu desain perencanaan, pelaksanaan, dan evaluasi. (1) Desain perencanaan terdiri dari 12 komponen yaitu: identitas sekolah, identitas mata pelajaran, identitas kelas dan semester, tema, sub tema, materi pokok, alokasi waktu, kompetensi inti, kompetensi dasar, indikator pencapaian kompetensi, tujuan pembelajaran, materi pembelajaran, metode pembelajaran, media pembelajaran, sumber belajar, langkah-langkah pembelajaran (sintak), dan penilaian hasil pembelajaran. (2) Desain langkah-langkah pembelajaran (sintak) terdiri dari 7 langkah, yaitu: identifikasi topik, membagi dan mengatur siswa kedalam kelompok, merencanakan tugas, 
melaksanakan investigasi, menyiapkan laporan akhir, mempresentasikan laporan akhir, dan evaluasi. (3) Desain evaluasi terdiri dari: penilaian proses sikap, penilaian proses keterampilan berpikir sejarah, dan penilaian hasil belajar.

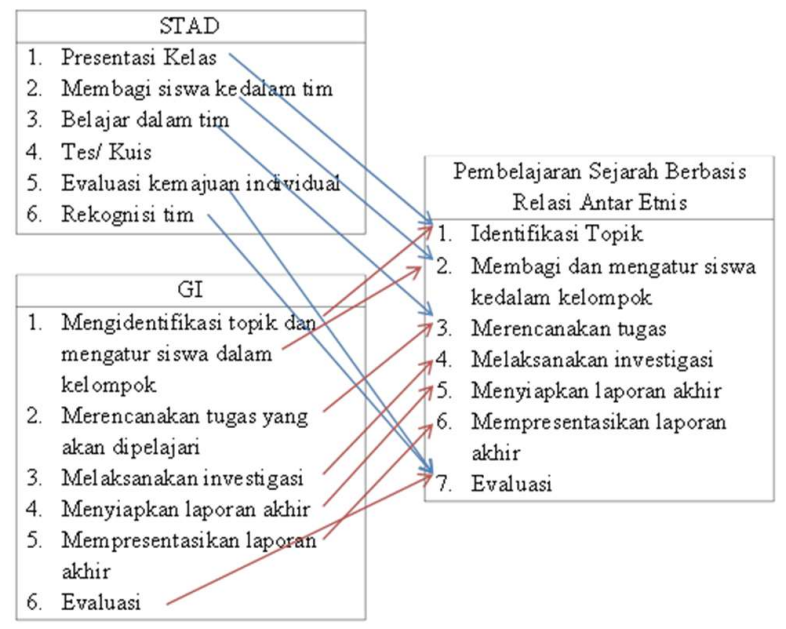

Gambar 1. Konsep modifikasi sintak model

Berikut deskripsi tiap-tiap langkah pembelajaran yang menjadi fokus model yang dikembangkan. Pertama, Identifikasi Topik. Merupakan presentasi guru untuk membawa siswa kepada problema sejarah yang akan dikaji. Ini merupakan perpaduan antara direct learning pada STAD dan mengidentifikasi topik pada GI. Sehingga tahap ini tidak sekedar komunikasi satu arah antara guru dan murid, melainkan juga komunikasi antar siswa dimana siswa diberi kesempatan untuk memberikan usul sub-topik yang akan dipelajari, seperti pada tipikal penentuan topik pada GI. Pada dasarnya identifikasi topik terdapat pada tahapan pendahuluan atau apersepsi. Tahap ini dilakukan setelah guru menyelesaikan kegiatan lain yang merupakan standar dalam langkah pendahuluan, seperti: mengucapkan salam, meminta siswa untuk berdoa bersama, mengecek kesiapan siswa dalam menerima pembelajaran, dan menyampaikan tujuan pembelajaran. Pada tahap ini guru memberikan kesempatan kepada siswa untuk memberikan usul sub tema yang akan dipelajari, kemudian siswa merespons dengan mengemukakan pengetahuan awalnya mengenai tema yang akan di kaji, dan memberikan usul sub-tema yang akan dipelajari. Kedua, Membagi dan mengatur siswa kedalam kelompok. Merupakan tahap dimana guru memfasilitasi terbentuknya kelompok yang terdiri rata-rata empat siswa per kelompok. Sub-topik akan dimunculkan oleh diskusi kelas, namun komposisi kelompok bukan berdasarkan ketertarikan siswa seperti pada pembentukan kelompok GI, melainkan berdasarkan keterwakilan heterogen dari kinerja akademik, jenis kelamin, ras, dan etnisitas seperti pada pembentukan kelompok STAD. Hal ini akan memunculkan komunikasi dan relasi antar etnis, sebagaimana yang ingin diamati. Dalam tahap ini siswa mengikuti instruksi guru untuk membentuk kelompok belajar. Tahapan ini masih dalam bagian langkah pendahuluan.

Ketiga, Merencanakan Tugas. Tahap ini dapat dikatakan sebagai langkah awal memasuki bagian inti pembelajaran. Guru dan siswa merencanakan pembagian tugas dalam kelompok beserta strategi pemecahan masalahnya. Guru mulai dengan membagikan lembar kerja siswa, sumbersumber sejarah primer/sekunder, dan artikel suplemen untuk diinvestigasi. Pada tahap ini siswa bermusyawarah secara demokratis untuk memilih ketua kelompok, notulen dan juru bicara, serta kemudian membagi tugas tiap anggota. Keempat, Melaksanakan Investigasi. Tahap ini merupakan praktik student center learning, dimana siswa menjadi pusat pembelajaran. Guru memberikan waktu sepenuhnya kepada siswa untuk memulai investigasi. Guru sekedar mengawasi untuk memastikan tiap kelompok bekerja maksimal dan memberikan bimbingan jika diperlukan. Pada tahap ini pula guru sudah dapat memulai penilaian proses. Sedangkan siswa berdiskusi aktif, mengumpulkan informasi, menganalisis data, bertukar informasi, mengklarifikasi, mensintesiskan hubungan antar 
fakta hingga merumuskan sebuah gagasan. Mereka mengeksplorasi semua sumberdaya belajar yang ada, mulai buku paket sejarah Indonesia, sumber-sumber sejarah primer/sekunder, internet, artikel suplemen, dan lain sebagainnya. Kelima, Menyiapkan laporan akhir. Pada tahap ini guru mengintruksikan siswa untuk mempersiapkan laporan akhir. Sedangkan siswa mulai mengakhiri kegiatan investigasinya untuk selanjutnya menentukan pesan-pesan esensial dari proyek mereka dan membuat perencanaan bagaimana mempresentasikannya. Keenam, Mempresentasikan laporan akhir. Pada tahap ini guru memfasilitasi siswa untuk presentasi masing-masing kelompok dan mengatur urutan presentasi. Tiap kelompok secara bergiliran melakukan presentasi hasil proyek mereka. Kelompok presenter memerankan diri sebagai ahli dan para pendengar mengevaluasi kejelasan dan penampilan presenter sehingga membuka ruang berdiskusi. Pada keseluruhan tahapan ini guru melakukan penilaian. Ketujuh, Evaluasi. Pada dasarnya tahap ini merupakan langkah penutup kegiatan pembelajaran. Guru mengajak siswa untuk melakukan evaluasi bersama tentang tugas yang telah mereka kerjakan. Guru mengumumkan hasil penilaian sebagai bentuk rekognisi kelompok. Selain itu guru juga mengajak siswa untuk melakukan refleksi mengenai makna dari peristiwa sejarah yang telah dikaji bersama. Siswa memberikan respon gagasan tentang evaluasi terhadap diri mereka sendiri maupun temannya dan mengungkapkan gagasannya mengenai refleksi peristiwa sejarah yang dikaji. Siswa juga dapat mengajukan pertanyaan mengenai beberapa hal yang dianggap belum jelas. Mengakhiri tahap ini, guru dapat melakukan langkah penutup lain seperti menginformasikan mengenai rencana pembelajaran pertemuan berikutnya dan diakhiri dengan doa serta salam.

Draft model kemudian divalidasi oleh ahli dan praktisi dengan uji coba di atas meja (desk evaluation), untuk menilai kelayakan draft model. Validator ahli atau pakar terdiri dari dosen pendidikan sejarah Universitas Nusantara PGRI Kediri yang meninjau model dari segi kelayakan dasar-dasar konsep maupun teori yang digunakan. Sedangkan Validator praktisi adalah para guru sejarah SMAN 1 Kota Kediri yang menilai kelayakan praktis model tersebut. Hasil validasi desain awal model pembelajaran RAE adalah sebagai berikut: Hasil validasi kelayakan pada aspek teori pendukung menunjukkan skor 84,53 yang berarti dalam kategori layak. Pada aspek kelayakan sintak, menunjukkan skor 87,63 yang berarti dalam kategori layak. Pada aspek kelayakan sistem sosial, menunjukkan skor 75,25 yang berarti dalam kategori cukup layak. Pada aspek kelayakan prinsip reaksi, menunjukkan skor 78,34 yang berarti dalam kategori cukup layak. Pada aspek kelayakan sistem pendukung, menunjukkan skor 75,25 yang berarti dalam kategori cukup layak. Pada aspek kelayakan dampak intruksional, menunjuukkan skor 84,53 yang berarti dalam kategori layak. Sedangkan pada aspek kelayakan dampak pengiring, menujukkan skor 75,25 yang berarti dalam kategori cukup layak. Nilai rerata skor keseluruhan aspek adalah 80,11 yang berarti dalam kategori layak. Secara umum para validator menyatakan bahwa desain awal model pembelajaran RAE dapat digunakan tanpa revisi, atau telah memenuhi kelayakan.

Setelah model dinyatakan layak, kemudian dilakukan uji coba lapangan pendahuluan. Uji coba lapangan pendahuluan ini terdiri dari dua jenis, yaitu pengujian model terbatas dan pengujian model perluasan. Fokus utama uji coba terbatas adalah menguji kelayakan implementasi langkahlangkah (sintak) pembelajaran, sedangkan uji coba perluasan bertujuan mengetahui kelayakan seluruh unsur-unsur model. Metode yang digunakan adalah penelitian tindakan (action research) yang dilakukan secara kolaboratif dan partisipatif. Desain yang digunakan adalah yang dikembangkan oleh Mc. Taggart dan Kemmis yaitu empat tahapan: perencanaan, pelaksanaan, observasi, dan refleksi. Ringkasan hasil uji coba lapangan pendahuluan dapat dilihat pada Tabel 1. Berdasarkan Tabel 1. dapat digambarkan bahwa terjadi peningkatan kualitas pada tiap siklus uji coba, hingga uji coba terakhir mendapat predikat baik $(85,01)$. Pada uji coba perluasan dilakukan pula analisis terhadap angket rasa solidaritas kebangsaan siswa melalui metode uji-t amatan ulang (paired sample t-test) pada pretes dan postes dengan hasil yang dapat dilihat pada Tabel 2. Sebagaimana terlihat pada Tabel 2 bahwa model pembelajaran RAE berdampak pada peningkatan rasa solidaritas kebangsaan siswa secara signifikan. Selanjutnya untuk mengetahui pengaruh penerapan model pembelajaran RAE dilakukan uji efektifitas model dengan metode eksperimen desain pretest-posttest control group dan menggunakan teknik analisis uji-t antar kelompok (independent samples t-test). Rangkuman hasil uji efektifitas model dapat dilihat pada Tabel 3. 
\begin{tabular}{l|l|l} 
Pendekatan relasi antar etnis untuk menungkatkan rasa ... & 151
\end{tabular}

Wahyu Pambudi, Sariyatun Sariyatun, Akhmad Arif Musadad

Tabel 1. Rangkuman Hasil Observasi Model

\begin{tabular}{|c|c|c|c|c|c|c|c|c|}
\hline \multirow{2}{*}{ Aspek } & \multicolumn{2}{|c|}{ UT-1 } & \multicolumn{2}{|c|}{ UT-2 } & \multicolumn{2}{|c|}{ UP-1 } & \multicolumn{2}{|c|}{ UP-2 } \\
\hline & Skr & $\mathrm{N} 1$ & Skr & $\mathrm{N} 1$ & Skr & N1 & Skr & N1 \\
\hline \multicolumn{9}{|l|}{ 1. Sintak } \\
\hline a. Identifikasi Topik & 75,25 & $\mathrm{C}$ & 83,50 & B & 75,25 & $\mathrm{C}$ & 83,50 & $\mathrm{~B}$ \\
\hline $\begin{array}{l}\text { b. Membagi dan } \\
\text { mengatur siswa } \\
\text { dalam kelompok }\end{array}$ & 75,25 & $\mathrm{C}$ & 91,75 & SB & 91,75 & SB & 91,75 & SB \\
\hline $\begin{array}{l}\text { c. Merencanakan } \\
\text { Tugas }\end{array}$ & 75,25 & $\mathrm{C}$ & 83,50 & B & 91,75 & SB & 91,75 & SB \\
\hline $\begin{array}{l}\text { d. Melaksanakan } \\
\text { Investigasi }\end{array}$ & 75,25 & $\mathrm{C}$ & 83,50 & B & 83,50 & B & 83,50 & B \\
\hline $\begin{array}{l}\text { e. Menyiapkan } \\
\text { Laporan Akhir }\end{array}$ & 75,25 & $\mathrm{C}$ & 75,25 & $\mathrm{C}$ & 83,50 & B & 83,50 & B \\
\hline $\begin{array}{l}\text { f. Mempresentasikan } \\
\text { Laporan Akhir }\end{array}$ & 58,75 & SK & 75,25 & $\mathrm{C}$ & 83,50 & B & 83,50 & $\mathrm{~B}$ \\
\hline g. Evaluasi & 50,50 & SK & 75,25 & $\mathrm{C}$ & 75,25 & $\mathrm{C}$ & 83,50 & B \\
\hline Rerata Sintak & 69,36 & K & 81,14 & $\mathrm{~B}$ & 83,50 & B & 85,86 & B \\
\hline 2. Prinsip Reaksi & & & & & 80,20 & B & 86,80 & B \\
\hline 3. Sistem Sosial & & & & & 73,19 & $\mathrm{C}$ & 81,44 & B \\
\hline 4. Sistem Pendukung & & & & & 93,40 & SB & 93,40 & SB \\
\hline 5. Dampak Intruksional & & & & & 75,25 & $\mathrm{C}$ & 81,44 & B \\
\hline 6. Dampak Pengiring & & & & & 75,25 & $\mathrm{C}$ & 81,44 & $\mathrm{~B}$ \\
\hline Rerata Seluruh Aspek & & & & & 80,13 & $\mathrm{~B}$ & 85,01 & B \\
\hline
\end{tabular}

Tabel 2. Hasil Angket Rasa Solidaritas Kebangsaan pada Uji Coba Perluasan

\begin{tabular}{|c|c|c|c|c|c|c|}
\hline No. & Uji & Data & Rerata & $t_{\text {hitung }}$ & Sig. & Ket. \\
\hline \multirow{2}{*}{1.} & \multirow{2}{*}{ UP-1 } & Pretest & 116,68 & \multirow{2}{*}{$-18,636$} & \multirow{2}{*}{0,000} & \multirow{2}{*}{ Signifikan } \\
\hline & & Posttest & 119,00 & & & \\
\hline \multirow{2}{*}{2.} & \multirow{2}{*}{ UP-2 } & Pretest & 113,21 & \multirow{2}{*}{$-8,185$} & \multirow{2}{*}{0,000} & \multirow{2}{*}{ Signifikan } \\
\hline & & Posttest & 115,24 & & & \\
\hline
\end{tabular}

Tabel 3. Hasil Anget Rasa Solidaritas Kebangsaan Siswa pada Uji Efektifitas Model

\begin{tabular}{|c|c|c|c|c|c|c|}
\hline No. & Data & Kelas & Rerata & $t_{\text {hitung }}$ & Sig. & Keterangan \\
\hline \multirow{2}{*}{1} & \multirow{2}{*}{ Pretest } & Eskperimen & 116,89 & \multirow{2}{*}{1,528} & \multirow{2}{*}{0,131} & \multirow{2}{*}{ Tidak Signifikan } \\
\hline & & Kontrol & 113,00 & & & \\
\hline \multirow{2}{*}{2} & Pretest & \multirow{2}{*}{ Eksperimen } & 116,89 & \multirow{2}{*}{$-10,816$} & \multirow{2}{*}{0,000} & \multirow{2}{*}{ Signifikan } \\
\hline & Posttest & & 119,17 & & & \\
\hline \multirow{2}{*}{3} & Pretest & \multirow{2}{*}{ Kontrol } & 113,00 & \multirow{2}{*}{$-1,717$} & \multirow{2}{*}{0,095} & \multirow[b]{2}{*}{ Tidak Signifikan } \\
\hline & Posttest & & & & & \\
\hline \multirow{2}{*}{4} & \multirow{2}{*}{ Posttest } & Eksperimen & 119,17 & \multirow{2}{*}{2,398} & \multirow{2}{*}{0,019} & \multirow{2}{*}{ Signifikan } \\
\hline & & Kontrol & 113,26 & & & \\
\hline
\end{tabular}


Sebagaimana pada Tebel 3, pada pretest diperoleh nilai sig. 0,131. Dengan menggunakan taraf signifikansi sebesar 0,05 , ternyata nilai sig. 0,131 lebih besar dari 0,05 . Bahwa nilai sig. $\leq \alpha$, maka $\mathrm{H}_{0}$ diterima, yaitu tidak ada perbedaan rasa solidaritas kebangsaan siswa antara kelompok eksperimen dan kelompok kotrol pada pretest. Ini berarti kedua kelompok berangkat pada kondisi awal yang sama sebelum perlakuan. Sedangkan pada posttest diperoleh nilai sig. 0,019. Dengan menggunakan taraf signifikansi sebesar 0,05, ternyata nilai sig. 0,019 lebih kecil dari 0,05. Bahwa nilai sig. $\leq \alpha$, maka $\mathrm{H}_{0}$ ditolak dan $\mathrm{H}_{1}$ diterima, yaitu ada perbedaan rasa solidaritas kebangsaan siswa antara kelompok eksperimen dan kelompok kontrol pada posttest. Jika dilihat pada rerata/mean posttest antara kelas eksperimen dan kelas kontrol, yaitu 119,17 pada kelas eksperimen ternyata lebih tinggi dibandingkan 113,26 pada kelas kontrol. Dengan ini dapat disimpulkan bahwa model pembelajaran RAE efektif untuk meningkatkan rasa solidaritas kebangsaan siswa. Dapat diuraikan bahwa faktor yang berpengaruh terhadap peningkatan rasa solidaritas kebangsaan siswa adalah pendekatan relasi antar etnis yang diinternalisasikan dalam pembelajaran RAE. Oleh karenanya sintak atau langkah-langkah pembelajaran menjadi dugaan utama yang telah mempengaruhi sikap solidaritas kebangsaan siswa. Metode atau langkah-langkah dalam pembelajaran RAE merupakan modifikasi dari dua metode pembelajaran kooperatif yaitu STAD dan GI, maka pembedahan karakteristik pada masing-masing metode membantu menjelaskan efektifitas perlakuan metode RAE terhadap sikap solidaritas kebangsaan siswa.

Karakteristik pembentukan tim dalam metode STAD yang diadopsi metode RAE, dimana keterwakilan heterogen dari kinerja akademik, jenis kelamin, ras, dan etnisitas menjadi perhatian utama pada pembentukan kelompok. Metode pembentukan kelompok ini dapat memberikan dampak positif terhadap relasi antar etnis. Umumnya perbedaan rasial ataupun etnik akan mendorong kecenderungan siswa untuk membentuk kelompok teman yang homogen, dan kadang berujung pada prasangka yang berlebihan dan kekejaman rasial. Namun dengan metode pembentukan kelompok pada metode STAD, kita dapat menguraikan homogenitas itu sehingga menghasilkan heterogenitas yang positif. Hal ini sesuai seperti yang diungkapkan oleh Slavin bahwa hasil penelitian di Amerika menunjukkan metode STAD menghasilkan hubungan pertemanan lintas-rasial yang terlihat kuat (Slavin, 2013, p.105). Lebih lanjut ia menambahkan bahwa STAD memberikan efek kepada jalinan pertemanan erat yang lintas etnik (Slavin, 2013, p.109-110).

Sementara itu gagasan utama dalam metode GI adalah bahwa kelompok di dalam kelas adalah prasyarat untuk bisa menghadapi berbagai masalah kehidupan yang kompleks dalam masyarakat demokrasi (Slavin, 2013, p. 214-215). Kelompok dijadikan sebagai sarana sosial dalam belajar, dan mendorong untuk memunculkan keterlibatan siswa secara maksimal. Pembelajaran ini mengedepankan dialog interpersonal di dalam kelas. Komunikasi dan dan interaksi kooperatif diantara sesama teman sekelas akan mencapai hasil maksimal apabila dilakukan dalam kelompok kecil. Karakteristik tahapan investigasi dalam metode GI yang sesuai dengan tuntutan pembelajaran sejarah kritis, relevan dengan pendapat Slavin (2013); metode group investigation mengedepankan penguasaan, analisis dan mensintesiskan informasi untuk menyelesaikan permasalahan. Pembelajaran sejarah yang menekankan pada praktik-praktik dan menempatkan mereka sebagai sejarawan memberikan konsekuensi bahwa mereka membutuhkan waktu dan ruang untuk langkahlangkah investigasi. Sehingga metode GI cukup ideal untuk langkah-langkah pembelajaran sejarah kritis. Seperti yang dikuatkan pula oleh Slavin (2013. P. 216) bahwa group Investigation akan sangat ideal untuk mengajari tentang pelajaran sejarah dan budaya dari sebuah negara. Ditinjau dari beberapa penelitian terdahulu, hasil ini sesuai dengan penelitian yang dilakukan oleh Supardan (2004).

Metodologi yang digunakan dalam penelitian ini adalah paradigma kualitatif, dengan desain kuasi-eksperimental. Beberapa temuan dalam penelitian ini yang relevan antara lain: pertama, bahwa terdapat pengaruh yang signifikan dalam pembelajaran sejarah dengan pendekatan multi-kultural terhadap hubungan antar-etnis dan solidaritas nasional. Kedua, bahwa pengaruh pembelajaran berbasis hubungan antar-etnis untuk membangun solidaritas nasional adalah signifikan. Keberhasilan model pembelajaran RAE dalam meningkatkan rasa solidaritas kebangsaan siswa hakikatnya memenuhi kriteria pendidikan nilai (value education). Sebagaimana harapan Wineburg (2006, p. 6), bahwa pendidikan sejarah memiliki potensi untuk menjadikan kita manusia berperikemanusiaan, hal yang tidak dapat dilakukan oleh semua mata pelajaran yang lain dalam kurikulum sekolah. Selain 
Pendekatan relasi antar etnis untuk menungkatkan rasa ...

Wahyu Pambudi, Sariyatun Sariyatun, Akhmad Arif Musadad

153

karakter rasa kebangsaan dan cinta tanah air, pembelajaran RAE yang mengedepankan keterampilan berpikir sejarah, dilihat dari langkah-langkah pembelajarannya, hakikatnya adalah pembelajaran dengan pendekatan ilmiah. Sejalan dengan Kurikulum 2013 yang menekankan dimensi pedagogik modern dalam pembelajaran, yaitu menggunakan pendekatan ilmiah (scientific approach) (Kementrian Pendidikan dan Kebudayaan Republik Indonesia, 2013, p. 181), pembelajaran RAE sesungguhnya turut membentuk watak siswa sebagai pribadi yang objektif, rasional dan ilmiah. Sehingga siswa dapat terbentuk pribadinya sesuai tantangan global abad 21.

\section{SIMPULAN}

Berdasarkan hasil penelitian dan pembahasan maka dapat disimpulkan: 1.) Hasil pengembangan model pembelajaran sejarah Indonesia berbasis relasi antar etnis di SMAN 1 Kota Kediri menunjukkan bahwa model pembelajarn RAE layak untuk diimplementasikan dan signifikan meningkatkan rasa solidaritas kebangsaan siswa; dan 2.) Model pembelajaran sejarah Indonesia berbasis relasi antar etnis efektif meningkatkan rasa solidaritas kebangsaan pada siswa SMA Kota Kediri. Hasil uji efektifitas model menunjukkan hasil t. 2,398, dengan taraf sig. 0,019 yang berarti model pembelajaran RAE efektif untuk meningkatkan rasa solidaritas kebangsaan siswa. Berdasarkan hal tersebut diatas, implikasi dalam penelitian ini, antara lain: 1.) Guru harus mengubah tradisi pembelajaran sejarah Indonesia sebagai transfer of knowledge menjadi pembelajaran yang berorientasi pada tradisi berpikir kritis, berdiskusi, mengeksplorasi sumber, membandingkan nilai, dan menimbang perasaan; 2.) Model pembelajaran RAE terbukti berpengaruh signifikan untuk meningkatkan rasa solidaritas kebangsaan siswa. Oleh karena itu pembelajaran sejarah Indonesia di SMA dianjurkan mengadopsi model pembelajaran RAE. Khususnya pada Kompetesi Dasar yang dipandang karakteristiknya sesuai dengan model pembelajaran RAE; dan 3.) Model pembelajran RAE diterapkan sebagai usaha membuat unit sejarah intelligible (dimengerti secara cerdas) dan pembelajaran dengan pendekatan ilmiah (scientific approach). Hal tersebut terwujud dalam tahapan pembelajaran disusun menyerupai bagaimana sejarawan bekerja (historian at work).

\section{DAFTAR PUSTAKA}

Ardi, A. M. (2017). Pancasila sebagai resolusi konflik: Relasi kuasa, agama, dan antar etnis di Indonesia pasca reformasi. Jurnal Damai dan Resolusi Konflik, 3(2), 35-60.

Budiawan, B. (2013). Titik simpang dan titik temu antara sejarah dan memori. Yogyakarta: Ombak.

Gall, M. D., Gall, J. P., \& Borg, W. R. (2003). Educational Research: An Introduction (7th ed.). USA: Pearson Education Inc.

Hasan, S. H. (2012). Pendidikan sejarah untuk memperkuat pendidikan karakter. Paramita: Historical Studies Journal, 22(1), 81-95. doi:https://doi.org/10.15294/paramita.v22i1.1875

Hasan, S. H. (2012). Pendidikan Sejarah Indonesia. Bandung: Rizqi Press.

Isnaini, M. (2016). Konsep pendidikan multikultural dalam merespon tantangan globalisasi analisis pemikiran HAR. Tilaar.

Kementrian Pendidikan dan Kebudayaan Republik Indonesia. (2013). Materi pelatihan guru implementasi kurikulum 2013 untuk SMA/MA dan SMK/MAK mata pelajaran sejarah Indonesia. Jakarta: Badan Pengembangan Sumber Daya Manusis Pendidikan dan Kebudayaan dan Penjaminan Mutu Pendidikan, Kementrian Pendidikan dan Kebudayaan Republik Indonesia.

Romli, K. (2015). Akulturasi dan asimilasi dalam konteks interaksi antar etnik. Ijtimaiyya: Jurnal Pengembangan Masyarakat Islam, 8(1), 1-13.

Siswanto, S. (2019). Pancasila sebagai pengawal solidaritas kebangsaan. Jurnal Pertahanan \& Bela Negara, 9(1), 109-124.

Slavin, R. E. (2013). Cooperative learning: Teori, riset, dan praktik. Bandung: Nusa Media. 
Supardan, D. (2004). Pembelajaran sejarah berbasis pendekatan multikultural dan perspektif sejarah lokal, nasional, global, untuk integrasi bangsa: Studi kuasi eksperimental terhadap siswa Sekolah Menengah Umum di Kota Bandung. (Unpublished doctoral dissertation). Universitas Pendidikan Indonesia, Indonesia.

Susanto, B. (2003). Identitas dan postkolonialitas di Indonesia. Yogyakarta: Kanisius.

Sutardi, T. (2007). Antropologi: Mengungkap keragaman budaya. Bandung: PT Grafindo Media Pratama.

Wineburg, S. (2006). Berpikir historis: Memetakan masa depan, mengajarkan masa lalu (Terjemahan Masri Maris). Jakarta: Yayasan Obor Indonesia. 